\title{
Christian Ethics Toward Crispr Cas-9 Gene Editing for Human Being
}

\author{
Daniel Fajar Panuntun \\ Sekolah Tinggi Agama Kristen Negeri Toraja \\ Jalan Poros Makale Makassar KM 11,5 Buntu Tangti, Mengkendek, \\ Kabupaten Tana Toraja, Sulawesi Selatan 91871 \\ nie1398@gmail.com
}

\begin{abstract}
The usage of Crispr Cas-9 technology for human being still make a lot of controversy world wide. Crispr Cas-9 has the potential to cure terminal diseases such as cancer. This phenomenon of Crispr Cas-9 technology becomes a problem because in the other side it's a method of editing at the gene level. Editing at the gene level can alter the core characteristic of a living thing; it can change them into superhuman, etc. Thus, the usage of this method can be dangerous. According to that matter, it's needed contribution from Christian ethics to the usage of the tecnology. Christian ethics is formulated from biblical study and literature to provide solution to the development of Crispr Cas-9 technology for human being. This research uses the qualitative and interdisciplinary methods. It's a phenomenology research by examining the proper Christian ethics for the use of Crispr Cas-9 technology. Data collection technique use Bible and literature studies that will be compiled a Christian ethics recommendation for the use of Crispr Cas-9 technology.
\end{abstract}

Keywords: Ethical, CRISPR CAS-9, Christian, Medical.

\section{Introduction}

Globalization occurs in all factors of human life. This has positive and negative impacts. Demographic changes due to global migration are a major influence on HIV / AIDS and children at risk. Internationally, WHO estimates that in 2020, diseases will often emerge such as cancer, diabetes, obesity and cardiovascular disease, which will cause $2 / 3$ of global diseases to exist, up $40 \%$ from now. This significant increase is a result of various global effects and mostly occurs in developing countries. In Indonesia, diseases that are increasingly developing due to changes in global demographics, one of which is HIV / AIDS with the highest number of sufferers are men. The disease is deadly threat in this developing world. Various terminal diseases and unknown treatments such as cancer and HIV / AIDS are increasing due to the influence of globalization.

The impact of Globalization on health is inevitable. Diseases that cannot be treated are growing. The discovery of the development of the CRISPR Cas9 gene application is a discovery that could be a solution above. CRISPR Cas9 technology can be used to engineer by targeting cancer cells so that it can be used as a treatment for the disease as well as other genetic diseases. This technology is a technology that is the answer to the anxiety of the global world of a growing disease.

The development of Crispr Cas-9 in the global world includes: lab experiments in gene cutting in mammals by pop-in pop-out techniques by Kuhn [1, pp. 2-3], this technology is used in the development of genetically modified wheat crops by Wang [2, p. 2].Eriksson also 
developed the same research on plant development through genetic engineering Crispr Cas-9 [3]. Crispr Cas-9 is an excellent genetic engineering tool for organisms today [4] this technology is increasingly being developed for genome editing in organisms [5, p. 1] and other research. The polemic in this research is the development of Crispr Cas-9 technology in humans. The researchers' focus is on problem cells edited in the present, but it is very difficult to predict future gene control and free use of the CRISPR Cas9 gene in addition to its importance as a solution to the disease [6, pp. 1-2] Based on the polemic there needs to be a medical ethic to provide answers. Christian ethics can make a contribution as a reference in the use of Crispr Cas-9 technology. Christian ethics based on the understanding of the Bible must be able to give a contribution of knowledge for the development of this technology related to its use to humans.

The focus of this research is how to formulate a model of Christian ethics for the use of Crispr Cas-9 technology for humans. It is hoped that from this research there is an appropriate model of Christian ethics so that the use of Crispr-Cas-9 can be used optimally for the good of humanity.

\section{Method}

This study uses a qualitative approach to the type of grounded theory [7] to be able to produce a new model of Christian ethics for the use of Crispr Cas-9 technology for humans. Data collection was carried out through a literature study on Crispr Cas-9, the views of figures on Christian ethics in genetic engineering and the study of the Bible. The data is then analyzed interactively [8] to provide a recommendation for a renewable ethical model.

\subsection{Crispr Cas-9 Controversy}

Crispr Cas-9 technology is a technology derived from the bacterial immune system. Based on the working principle of a bacterial immune system that can target foreign DNA / RNA that enters the bacterial DNA / RNA, this is the principle of genetic engineering through Crispr Cas-9 Technology [4, pp. 7-8]. This technology can target one DNA in the DNA complex string to be deleted or cut or inserted / added. That principle is what makes this technology special and can be continuously developed specifically in the medical industry. The principle of this bacterial immune system can be used to cure human disease by directly targeting problematic DNA strands and causing disease.

Crispr Cas-9 technology has various uses. These uses are first, in the field of biomedical for cell development and animal development. Second, in the field of optimizing plant genomes and developing biofuels. Third, in the field of medicine, it can be used to cure certain diseases $[9$, pp. 7-8] Surely this has become a controversy when this technology began to be applied for humans. Biomedical ethics emphasizes that in research the area of ethical issues must prioritize the benefits taken compared to the risks received. Crispr Cas-9 has a very scary future impact on the environment but has strength in the medical industry [6, p. 2.]. This technology is a new invention in this era, which is very revolutionary in the medical industry. This revolutionary discovery was also accompanied by a fear of the impact that would later be likely to result from the use and development of Crispr Cas-9 technology in general in the medical industry.

Crispr Cas-9 is a very powerful tool in the application of genetic engineering today. This technology makes genetic engineering very easy and effective to do. The concept of gene 
marking is then carried out cutting / deletion or insertion / insertion into the main strength of this technology $[4$, p. 1]. This technology is a tool that has been provided by nature in the process of genetic engineering. The use of this technology to humans is still accompanied by quite serious debate. This resulted in a controversy in the use of this technology $[9, \mathrm{p} .9]$. Negative things related to the use of this technology are: First, it causes damage to the ecological balance if there is editing to the gene level. Second, there is gene damage in humans. Third, the difficulty of control in the use of gene levels in the wider community $[6, p$. $3]$. These risks need to be considered in determining ethical decision making related to the use. A benefit in the medical industry is the use of this technology is effective in curing terminal illnesses. This technology is able to cure HIV disease [10] and able to reduce cervical cancer globally [11]. Both the facts of the advantages and disadvantages of the Crispr Cas-9 technology have caused controversy in its use. The application of this technology has not yet been developed globally because of the moral controversies in it.

\subsection{Bio Medic in Christian Ethic}

The Bible's view of the issue of biomedical gene editing according to Harub is to place the Bible the way it is. The Bible must be kept accurate to answer the problem [12, pp. 9-10]. This epistemology must be the basis for thinking about the formulation of ethical models related to biomedicine especially in the field of genetic engineering. The Bible can provide a single reference, although it does not directly answer all questions in the industry of biomedical ethics related to genetic engineering.

The various views of figures in ethics are described as follows. Utilitarianism ethics sees profit is the highest moral truth. Utilitarianism ethics is divided into two. Jeremy Betham [13, p. 5] writes quantitative utilitarianism which states that the highest moral truth is truth that is pleasing not to oneself but to many people. The more choices made benefit for many people, this is a moral truth. John Stuart Mill [14, p. 409] write qualitative utilitarianism which states that moral truth is truth that can give pleasure not in terms of number and duration but in terms of quality and it becomes a moral truth. The figure explained that Christian truth is the truth seen from it that is pleasing to society in general. This view when applied to the use of Crispr Cas-9 technology is seen by weighing the good and the bad. If the adverse effects are too many, this should be avoided.

The views of Catholic figures state that genetic engineering is carried out in differences, which must be stated significantly. Catholic moral theologians reject genetic engineering in humans but it is not a problem for animals or plants. This is based on the fact that genetic engineering in humans is far more dangerous. Continued genetic engineering in humans specifically for the therapeutic field of Catholic experts is more lenient to respond. This is based on the principle of patient moral autonomy and the principle of totalitation in which one part of the body can be sacrificed to save the patient [15, pp. 208-209]. Based on this, Catholic views are more lenient in the use of Crispr Cas-9 technology.

Norman Geisler's views represent the views of Christianity. Ethics used are multilevel absolute ethics. This ethical view is based on the following points in the decision making process. The underlying things are: first, Christian ethics are based on the will of God. Second, Christian ethics is absolute. Third, Christian ethics is prescriptive or formulating moral actions. Fourth, Christian Ethics is deontological, that is, seeing the whole process of determining the moral right or wrong [16, pp. 15-19]. Seeing this, Christian Ethics must be able to formulate the act of using Crispr Cas-9 with deontology, absolute and based on the will of God. 


\subsection{Bible's View}

Disease is one of the causes of death. Death in the Bible is a reward for sin. This happens when humans first fall into sin and then God gives judgment. The punishment is given to humans and also to the world. Humans and the world gradually become damaged and one of them appears a lot of diseases. A loving God does not allow this but saves humanity by giving protoevangelium. Uniquely there is something else that God gave to humans, stated in the Genesis 3:22, God gave an explanation that in the end humans can have knowledge about something good and bad.

Genesis 3:22 is a form of God's blessing among the judgments given to humans. This is an irony for God but for humans it shows a loving God. God allows the good and the bad knowledge to remain in human life [17, p. 42]. Even though humans do sin, God gives one gift so that humans can survive, that is knowledge of good and bad. This is known as Ethics. Based on this interpretation God allows humans to have knowledge of ethics and does not allow touching the fruit of life so that humans can survive in a world given by God. Humans must be able to survive by using the ethics bestowed by God. Based on this reasoning and human thought can be used to work for the good of human life as long as it is not used to equal God or commit the first sin. The use of this ethic is the basis for the use of Crispr-Cas9 technology for humans today. This is based on striving for a life for people who fall into sin and a world that is gradually getting worse.

\section{Result and Discussion}

The data display above explains the controversy regarding the use of Crispr Cas-9. Strengths and weaknesses have been presented based on the data above. Based on the studies of Christian Ethics theory above can be used to answer the use of Crispr Cas-9 in humans. The use of Crispr Cas-9 in humans is permitted for medical or treatment reasons. This is in accordance with the opinions of utilitarians, experts in Catholic ethics and Christian ethics according to Norman Geisler. The Bible gives the view that humans are allowed to strive for goodness in their lives through God's gifts of thought to distinguish the good from bad.

The use of Crisprs Cas-9 must be severely restricted in the medical field to humans. This is intended to cure various diseases such as cancer and HIV that are increasingly developing at this time. The use of Crispr Cas- 9 must be carried out transparently for medical purposes by taking into account the first characteristic that everything must be according to God's will, that is, human well-being and good living is God's will. Second, the absolute use of Crispr Cas-9 is only intended for the medical field in the context of healing terminal diseases. Third, the use of Crispr Cas-9 must be to formulate a medical action, which has the meaning to seek patient healing not for other purposes. Fourth, the use of Crispr Cas-9 must be deontological in nature that every method must be carried out properly, correctly and not in violation of existing norms. If the use of Crispr Cas-9 is carried out with the principles above, any negative impact of Crispr Cas-9 will be minimized in the real application of the medical world globally. Global society will be able to enjoy the benefits of Crispr Cas-9 technology specifically for the healing of terminal illnesses and HIV / AIDS. 


\section{Conclusion}

This research resulted in the formulation of a Christian ethical model for the use of Crispr Cas-9 to humans. The use of Crisprs Cas-9 must be severely restricted in the medical field. The use of Crisprs Cas-9 must be carried out in accordance with God's will, absolute use in the medical field only, must be prescriptive / formulate actions for healing, and be deontological in nature which means that every means used must be right. The impact of this ethical model is expected to contribute to medical ethics globally in accordance with the Christian faith and later Crisprs Cas-9 technology can be used optimally for the healing of human diseases.

\section{References}

[1] R. Kühn and V. T. Chu, "Pop in, pop out: A novel gene-targeting strategy for use with CRISPRCas9," Genome Biol., vol. 16, no. 1, 2015.

[2] W. Wang, A. Akhunova, S. Chao, and E. Akhunov, "Optimizing multiplex CRISPR/CAS9Cas9 system for wheat genome editing," bioRxiv, 2016.

[3] I. Eriksson, "CRISPR Cas9 system for plant genome editing within the European Union," Swedish University of Agricultural Sciences, 2015.

[4] H. Wang, M. La Russa, and L. S. Qi, "CRISPR/Cas9 in Genome Editing and Beyond," Annu. Rev. Biochem., vol. 85, no. 1, pp. 227-264, 2016.

[5] P. D. Hsu, E. S. Lander, and F. Zhang, "Development and Applications of CRISPR-Cas9 for Genome Engineering," HHS Public Access, vol. 157, no. 6, pp. 1262-1278, 2014.

[6] Rodriguez, "Ethical Issues in Genome Editing using Crispr/Cas9 System,” J. Clin. Res. Bioeth., vol. 07, no. 02, pp. 7-10, 2016.

[7] Sugiyono, Metode Penelitian dan Pengembangan (Research and Development). Bandung: Alfabeta, 2015.

[8] M. B. Miles and A. M. Huberman, Qualitative Data Analysis: A Sourcebook of New Methods. California: SAGE publications, 1982.

[9] Y. L. Xu and Q. Xu, "Development, Applications, and Ethical Complication of CRISPR Cas9 system in genome editing," United States, 2017.

[10] J. Erikania, "Berkat 'Gunting Molekuler', Ilmuwan Berhasil Hapus HIV Secara Permanen," 2016. [Online]. Available: https://nationalgeographic.grid.id/read/13304563/berkat-guntingmolekuler-ilmuwan-berhasil-hapus-hiv-secara-permanen?page=all. [Accessed: 12-Aug-2019].

[11] F. A. Damara, "CRISPR / Cas9 dengan Dual-sgRNAs Bertarget Gen E6 dan E7 Virus HPV 16 Sebagai Inovasi Terapi Gen Upaya Menurunkan Angka Kanker Serviks Global,” vol. 3, pp. 98 103, 2017.

[12] B. Harrub and B. Thompson, The Christian and Medical Ethics. alabama, 2004.

[13] J. Betham, Introduction to the principle of Morals and Legislation. New York: Hafner, 1965.

[14] J. S. Mill, Utilitarianism, in the Utilitarians. New York: Dolphin Book, 1961.

[15] P. Hadiwardoyo, "Rekayasa Genetis dalam Penalaran Teologi Moral Katolik," in MANTAP DALAM BERHARAP PASTI DALAM MISTERI, Yogyakarta: Kanisius, 2001.

[16] N. L. Geisler, Christian Ethics: Contemporary Issues and Option. Grand Rapid: Baker Academic, 2010 .

[17] R. Jamieson, A. R. Fausset, and D. Brown, Commentary Critical and Explanatory on the Whole Bible. Grand Rapid, MI : Christian Classics Ethereal Library, 2009. 